\title{
Post-caesarean section pain and quality of sleep among mothers who delivered by caesarean section under spinal anesthesia
}

\author{
Ririn Harini, Juwitasari, Lilis Setyowati, Rifdah Dita Oktavia
}

Faculty of Health Science, University of Muhammadiyah Malang.

*Corresponding author. Email: juwita@umm.ac.id

\begin{abstract}
Background: Post caesarean section mothers commonly feel pain in the post-operative area during the wound healing process. Most post-operative mothers feel the pain sensation as a disturbance and lowering their quality of sleep.

Purpose: To determine pain level and identify the relationship of pain level and sleep quality among mothers who delivered by caesarean section under spinal anaesthesia.

Method: The descriptive non-experimental correlative study design identified 50 mothers from Inpatient Ward Wava Husada Hospital of Kepanjen, Malang, East Java, Indonesia at April 2020. The Post-caesarean section pain level identified by using the Numeric Rating Scale (NRS) and the sleep quality is measured using Pittsburgh Sleep Quality Index (PSQI) questionnaire.

Results: 38 mothers (76\%) had severe pain level and most of them (43 mothers) had poor sleep quality. The Spearman correlation test showed that there was a relationship between the Post-caesarean section pain level and sleep quality, $p$ value $=0.000(p<0.05)$ and $r=0.314$.

Conclusion: The post-caesarean section pain levels among mothers who delivered by caesarean section under spinal anaesthesia should be identified earlier as we would like to encourage the nursing staff to give further intervention to maintain their sleep quality.
\end{abstract}

\section{Keywords : Post-caesarean section; Pain level; Mothers; Quality of sleep}

\section{INTRODUCTION}

Caesarean Section or what is known as a Csection is a surgical process that perform some incisions in the abdominal wall and uterus in order to deliver babies from the mother's womb who have particular complication (Marfuah et al., 2019). The recent decade shows the significant rise of $\mathrm{C}$ section incidence as the most frequent surgical intervention both in developed and developing countries (Jasim et al., 2017). The latest world epidemiological study in 2015 report that the Csection rate arise until $21.1 \%$ (29.7 million births) of the total delivery method (Boerma et al., 2018). Furthermore, about 1 in 5 mother have severe acute post $\mathrm{C}$-section pain which can develop to chronic pain (Gamez \& Habib, 2018).

The chronic pain that occur as persistent pain after C-section can influence for almost 10-50\% post C-section mother which bring serious concern to the condition of post C-section mother (Sun \& Pan, 2019). The post C-section incision could bring various complication such as the nervous damage, thromboembolic, inflammation, and many unwanted complication to both mother and babies (Yimer \& Woldie, 2019). Caesarean section complication to mother generally resulting moderate to severe pain in the post operation site from the first 48 hours until 2 months after surgery (Lee et al., 2018).

The further development of pain that resulted from C-section can delay the bonding attachment and causing bad impact to baby (AKTAŞ et al., 2020). The various post $C$-section pain reaction is very subjective depending on the mother's personality, emotional status, cultural, family history, educational levels, and previous experiences will stimulate the neurosensory (Lee et al., 2018). Thus, the need of Post-caesarean section pain level identification is very essential to set up the proper intervention and identify the response of care from the mother who experience the C-Section (Gupta et al., 2016).

The common response of post C-section mothers are poor sleep quality. More than $70 \%$ of the post $\mathrm{C}$-section mothers have experience with slow wave sleep and frequent waking episodes 
which causes poor sleep quality that lowering their quality of life (Ko et al., 2015). However, only few studies from developing country in clinical settings which identify the Post-caesarean section pain level, after $\mathrm{C}$-section surgery and its relation with the sleep quality, and the significant factors that lowering sleep quality of post C-Section mothers.

\section{RESEARCH METHODS}

This cross-sectional descriptive correlational study identifies the Post Caesarean section pain level, and its correlation to sleep quality and the significant factors that lowering sleep quality of post C-section mothers in maternity ward of The Wava Husada Hospital Kepanjen, Malang Sub district, East-Java Province of Indonesia in April 2020.

\section{Samples and Participants}

The selection of participants in this study using purposive sample technique of 132 mothers in April 2020 who underwent C-section who meet the inclusion criteria. The inclusion criteria in this study are the second day of post C-section mothers between 20-45 years old, experience with spinal anaesthesia, having no verbal communication problem, in the normal range of vital sign and agree to actively participate in this study. Furthermore, the exclusion criteria in this study are the mother with complication of post C-section procedure and refuse to participate during this study. The participants who meet inclusion criteria in this study is 50 mothers.

The demographic data collection of the participants was identified using 6-questions descriptive characteristics of mothers who underwent a $\mathrm{C}$-section (including age, level of education, occupation, parity, and frequency of $\mathrm{C}$ section procedure).

The Numeric Rating Scale (NRS) is applied in this study to identify the Post-caesarean section pain level of post $\mathrm{C}$-section mothers. The numeric rating scale was chosen because this scale is easier to record for pain assessment and has the good validity ( $r=0.83$ ) and reliability (The Cronbach Alpha reliability coefficient was 0.95 ) based on previous post-operative study (Karcioglu et al., 2018). Likewise, the participants in this study is asked about her Post-caesarean section pain level, and they need to choose which number that reflect her Post-caesarean section pain level.

The range of numeric rating scale is between 0 - 10 (0: means no pain; 1 to 2: mild pain; 3 to 4 : moderate pain; 5 to 6 : severe pain; 7 to 8 : very severe pain; 9 to 10: most severe pain). Moreover, the Post-caesarean section pain level measurement within the second day of post Csection (Tapar et al., 2018).

The Indonesian version of Pittsburgh Sleep Quality Index (PSQI) Questionnaire is used for the dependent variable to identify the quality of sleep. The PSQI questionnaire consists of 7 components, namely subjective sleep quality, sleep latency, sleep duration, sleep efficiency, sleep disturbances, use of sleeping pills, and daytime dysfunction. Sleep quality was measured by adding up the 7 scores of sleep quality components with a standardized formula. The higher the score, the worse the quality of sleep in participants. The Indonesian version of PSQI has acceptable internal consistency (Cronbach's= 0.83) and excellent concurrent validity $(r=0.89)$ (Abang \& Karangasem, 2019).

\section{Data Collection Procedure}

The data collection procedure is beginning after the approval letter issued by the Head of Bakesbangpol office (National Unity and Political Office) of Malang Regency. A cover letter sent from the Malang Regency Bankesbangpol office for conducting a research to the Head of Wava Husada Kepanjen Hospital. After obtaining permission for preliminary study and research from the Head of the Wava Husada Hospital Kepanjen, the person in charge of the Health Research Ethics Committee at Wava Husada Hospital help to take care of the ethical feasibility of the research and contacting the coordinator of the Head of Inpatient Room, Wava Husada Hospital Kepanjen. The data collection was conduct daily by distributing questionnaires given to participants. The researcher approaches the participants by introducing and explaining the aims and objectives of this study. The data collection at Wava Husada Hospital was carried out during the Covid-19 pandemic. As consequences, the distance 
between the researcher and the participants kept in 2 meters away. One research assistant (head of the maternity ward) accompany the researcher starting from data collecting informed consent form. Data Analysis and Ethical Consideration

The Statistical Package for Social Sciences (SPSS) version 23.0 is used for the data analysis. The univariate analysis was used to analyze the descriptive statistic of demographic variable. The normality test was performed before conduct bivariate analysis and the result showed that both the data of Post-caesarean section pain level and sleep quality were not normally distributed (sig $<0.05$ ). Thus, spearman correlation was applied to identify the bivariate analysis. The significant factors that lowering sleep quality identified by using logistic regression.
The cut-off point for Post-caesarean section pain level using Numeric Rating Scale (NRS) refer to the latest study that categorize the NRS into mild, moderate, or severe pain (score 1-5: mild, scores 6-7: moderate, and score 8-10: severe) (Boonstra et al., 2016). The cut of point of sleep quality using The Indonesian version of Pittsburgh Sleep Quality Index (PSQI) Questionnaire adapt the recent study in clinical settings (the optimal cutoff was $>7$ for self-reported poor sleepers) (Gomes et al., 2018). The study procedure has been examined by The Committee of Ethical Exemptions of Wava Husada Hospital on February $11^{\text {th }}, 2020$ legalized by the official letter of accordance number 2363/JWB/RSWH///2020. The declaration of ethically appropriate in accordance to $11 \mathrm{WHO}$ Standards.

\section{RESULTS}

Table 1. Demographic Characteristics of Participants $N=50$

\begin{tabular}{lccc}
\hline \multicolumn{1}{c}{ Demographic } & $\mathbf{n}$ & $\%$ & $\mathbf{M} \pm \mathbf{S D}$ \\
\hline Age (Year)(Range: 20-45) & 50 & & $30 \pm 5.6$ \\
Level of education & & & \\
Junior high & 4 & $8 \%$ & \\
Senior high & 36 & $72 \%$ & \\
Diploma & 10 & $20 \%$ & \\
Occupation & & & \\
Housewife & 42 & $84 \%$ & \\
Government employees & 8 & $16 \%$ \\
Parity & & & \\
1 & 19 & $38 \%$ \\
2 & 27 & $54 \%$ \\
3 & 4 & $8 \%$ \\
C-Section Frequency & & \\
1st $^{\text {2nd }}$ & 37 & $74 \%$ \\
$3^{\text {rd }}$ & 12 & $24 \%$ \\
\hline
\end{tabular}

Ririn Harini, Juwitasari*, Lilis Setyowati, Rifdah Dita Oktavia

Faculty of Health Science, University of Muhammadiyah Malang. *Corresponding author. Email: juwita@umm.ac.id 
The demographic data among 50 post C-section mothers, between 20 and 45 years old showed in (Table I). The mean age of mothers was $30 \pm 5.6$ years. The level of education characteristics of the $\mathrm{C}$-section mothers $(72 \%)$ is senior high school. Most of participants $(84 \%)$ become a housewife and $(74 \%)$ have the first experience of C-section. More than half of participants (54\%) gave birth to her second children.

Table 2.Post-Caesarean Section Pain and Quality of Sleep N=50

\begin{tabular}{lcc}
\hline Variables & $\mathbf{n}$ & $\%$ \\
\hline Post-Caesarean Section Pain & & \\
1-3 : mild pain & 3 & $6 \%$ \\
4-6 : moderate pain & 9 & $18 \%$ \\
7-10 : severe & 38 & $76 \%$ \\
Quality of Sleep & & \\
Good sleep quality (score $<7)$ & 29 & $58 \%$ \\
Poor sleep quality (score $\geq 7)$ & 21 & $42 \%$ \\
\hline
\end{tabular}

Three quarter of the total participants $(76 \%)$ experienced severe pain levels during second day of C-section procedure. More than half of participants classified had good sleep quality. A moderate significant correlation was found between the Post-caesarean section pain level and sleep quality on the second day of post C-section Mothers $(r=0.314 ; p=0.001)$.

Table 3. Correlation of Post-Caesarean Section Pain and Quality of Sleep

\begin{tabular}{lll}
\hline \multicolumn{1}{c}{ Variables } & p-value & $\mathbf{r}$ \\
\hline $\begin{array}{l}\text { Post-caesarean section pain level and } \\
\text { quality of sleep }\end{array}$ & 0.026 & 0.314 \\
\hline
\end{tabular}

\section{DISCUSSION}

More than three quarter of posts C-section Mothers $(76 \%)$ experienced severe pain in the second day after surgery. It may caused from the inflammatory reaction after the first 48 hours of surgery that profound the severe painful sensation in the nerve endings surrounding post-operative site (Silva et al., 2017). The severe pain sensation can be developed as chronic pain when some factors like the lack of pain control which worsen the post-operative pain sensation (Yimer \& Woldie, 2019).
The pain sensation also influenced by the previous labour experience (Paine et al., 2020). The results of other studies showed that post Csection delivery in primiparous often experienced a higher level of labor pain than multiparous, namely 2.63 times (95\%). This is because multiparous experiences effacement (cervical thinning) along with cervical dilation, whereas in primiparous the effacement process usually occurs earlier than cervical dilation (Shuchi et al., 2019). Age factor, gender, parity, culture, attention, coping style anxiety, and previous experiences will affect the

Ririn Harini, Juwitasari*, Lilis Setyowati, Rifdah Dita Oktavia

Faculty of Health Science, University of Muhammadiyah Malang. *Corresponding author. Email: juwita@umm.ac.id 
pain level related to the incision of the abdominal wall tissue and the wall of the uterus which can cause changes in the continuity (Knudsen et al., 2020).

More than half of participants have first experience of having $\mathrm{C}$-section surgery, which can lowering her capability to cope and to control her capacity in dealing with their painful condition (Marfuah et al., 2019). Thus, this condition may lower their chance to have good sleep quality. During the post $\mathrm{C}$-section period, mothers normally need more sleep than normal condition. However, the severe pain disturb their rhythm of sleeping and waking (Fitri et al., 2012). The pain sensation after C-section can develop the poor sleep quality through two distinct way like the pain interrupts sleep, and fragmented sleep (Quinlan, 2019). The participant could have potential losses in the accomplishment of performing her daily activities as usual due to the poor sleeping condition (Silva et al., 2017). Mothers feel more exhausted and only have sleeping time less than 5 hours in a day compared to mothers with vaginal delivery (Majzoobi et al., 2004).

More than half (58\%) of post C-section mothers categorized as not poor sleepers. However, most of study predict the different result that mother with short sleep duration were 4.5 times having csection experience (Zafarghandi et al., 2012).

Based on the statistical analysis of the results of the Spearman Rank correlation test using SPSS 23 , the value of $p=0.314$ was obtained, because the value of $p<0.05$ means that there is a correlation between the scale of post sectio caesarean wound pain and sleep quality at Wava Husada Hospital Kepanjen. The results stated that there was a correlation with $(+)$ correlation between post sectio caesarean wound pain and sleep quality. The direction of the correlation in question is unidirectional, meaning that the higher the pain level of the post-sectio caesarean mother, the worse the quality of sleep is.

The results of this study are in accordance with the results of research conducted by Fitri (2012) regarding the relationship of the intensity of pain in sectio caesarea with the sleep quality of post partum patients on day 2 with the results of the study which showed that there was a relationship between sectio caesarean wound pain and the quality of sleep in post partum day patients. 2 nd in the Sumedang Hospital inpatient ward.

\section{RESEARCH LIMITATIONS}

On In this study there are limitations to the COVID-19 pandemic, which causes the samples taken to be limited only according to hospital regulations.

\section{CONCLUSION}

The study highlights that more than half of the respondents experience severe pain and almost half of them have poor sleep quality. It is necessary to know the postoperative pain levels should be emphasized as we would like to encourage the nursing staff to give further support to maintain their sleep quality.

\section{REFERENCES}

Abang, K., \& Karangasem, K. (2019). Reliabilitas Kusioner Pittsburgh Sleep Quality Index ( PSQI ) Versi Bahasa Indonesia Dalam Mengukur. 3(2).

Aktaş, D., İskender, Ö., \& Topaloğlu, M. G. (2020). Relationship Between the Level of Pain and Quality of Sleep in Women After a Cesareansection. Bezmialem Science, 8(1), 62-67. https://doi.org/10.14235/bas.galenos.2019.3183

Boerma, T., Ronsmans, C., Melesse, D. Y., Barros, A., Barros, F. C., Juan, L., Moller, A.-B., Say, L., Hosseinpoor, A., Yi, M., De Lyra Rabello Neto, D., \& Temmerman, M. (2018). The global epidemiology of Caesarean Sections: major increases and wide disparities. The Lancet. https://doi.org/10.1016/S0140

Boonstra, A. M., Stewart, R. E., Köke, A. J. A., \& Oosterwijk, R. F. A. (2016). Cut-Off Points for Mild, Moderate, and Severe Pain on the Numeric Rating Scale for Pain in Patients with Chronic Musculoskeletal Pain: Variability and Influence of Sex and Catastrophizing. 7(September), $\quad$ 1-9. https://doi.org/10.3389/fpsyg.2016.01466 
Fitri, M., Trisyani, M., \& Maryati, I. (2012). Hubungan Intensitas Nyeri Luka Sectio Caesarea Dengan Kualitas Tidur Pada Pasien Post Partum Hari Ke-2 Di Ruang Rawat Inap Rsud Sumedang. Milla Fitri Fakultas IImu Keperawatan Universitas Padjadjaran (JI. Raya Bandung - Sumedang KM, 21, 1-14.

Gamez, B. H., \& Habib, A. S. (2018). Predicting severity of acute pain after cesarean delivery: A narrative review. Anesthesia and Analgesia, 126(5), 1606-1614. https://doi.org/10.1213/ANE.000000000000265 8

Gomes, A. A., Marques, D. R., Maria, A., Filipa, M., \& Vanda, C. (2018). Psychometric properties and accuracy of the European Portuguese version of the Pittsburgh Sleep Quality Index in clinical and non- clinical samples. Sleep and Biological Rhythms, $\quad 0(0), \quad 0$. https://doi.org/10.1007/s41105-018-0171-9

Gupta, N., Gupta, S., Agarwal, A., Agarwal, S., \& Mahto, R. (2016). A comparison of visual analog scale and Wong Baker facial Postcaesarean section pain for pain measurement in post lower caesarean section case. International Journal of Reproduction, Contraception, Obstetrics and Gynecology, 5(9), 3032-3035. https://doi.org/10.18203/23201770.jijrog20162979

Jasim, H. H., Sulaiman, S. A. B. S., Khan, A. H., \& Rajah, U. A. S. (2017). Factors affecting post caesarean pain intensity among women in the northern peninsular of Malaysia. Journal of Clinical and Diagnostic Research, 11(9), IC07IC11. https://doi.org/10.7860/JCDR/2017/25364.1063 0
Karcioglu, O., Topacoglu, H., Dikme, O., \& Dikme, O. (2018). American Journal of Emergency Medicine A systematic review of the Postcaesarean section pains in adults: Which to use? American Journal of Emergency Medicine, 36(4), 707-714. https://doi.org/10.1016/j.ajem.2018.01.008

Knudsen, R. K., Kruse, A. R., \& Lou, S. (2020). Parents' experiences of early discharge after a planned caesarean section: A qualitative interpretive study. Midwifery, 86, 102706. https://doi.org/10.1016/j.midw.2020.102706

Ko, Y. L., Lin, P. C., \& Chen, S. C. (2015). Stress, sleep quality and unplanned Caesarean section in pregnant women. International Journal of Nursing Practice. https://doi.org/10.1111/ijn.12267

Lee, J., Nagarajan, S., Tan, C. W., \& Sng, B. L. (2018). Persistent post-Caesarean pain. Trends in Anaesthesia and Critical Care, 20, 26-31. https://doi.org/10.1016/j.tacc.2018.04.003

Majzoobi, M. M., A, M. R. M. M., Nazari-, F., Biglari, M., \& Poorolajal, J. (2004). Comparing Quality of Life in Women after Vaginal Delivery and Cesarean Section. Md.

Marfuah, D., Nurhayati, N., Mutiar, A., Sumiati, M., \& Mardiani, R. (2019). Pain Intensity among Women with Post-Caesarean Section: A Descriptive Study. KnE Life Sciences, 2019, 657-663.

https://doi.org/10.18502/kls.v4i13.5322

Paine, S., Signal, T. L., Sweeney, B., Priston, M., Muller, D., Smith, A., Huthwaite, M., Stell, M., Sa, F., Gander, P., \& Lee, K. (2020). Maternal sleep disturbances in late pregnancy and the association with emergency caesarean section : A prospective cohort study. Sleep Health: Journal of the National Sleep Foundation, 6(1), 65-70.

https://doi.org/10.1016/j.sleh.2019.11.004 
Quinlan, J. (2019). Caesarean delivery: Bringing more than just a bundle of joy. Canadian Journal of Pain, 3(2), 5-9. https://doi.org/10.1080/24740527.2019.157453 8

Shuchi, F. A., Lovereen, S., \& Mina, M. N. (2019). Outcome of Mode of Delivery in Nulliparous and Multiparous Women Presenting with Early and Late Cervical Dilatation. Delta Medical College Journal, 7(1), 16-20. https://doi.org/10.3329/dmcj.v7i1.40616

Silva, T. C., Silva, B., \& Tatagiba, F. (2017). Postoperative pain in women undergoing caesarean section Dor pós-operatória em mulheres submetidas à cesariana abstract: 374-383.

Sun, K. W., \& Pan, P. H. (2019). Persistent pain after cesarean delivery. International Journal of Obstetric Anesthesia, 40, 78-90. https://doi.org/10.1016/j.jjoa.2019.06.003
Tapar, H., Karaman, S., Dogru, S., Karaman, T., \& Dogru, H. Y. (2018). Evaluation of Postoperative Analgesic Consumption After Emergency and Elective Cesarean Section. Gynecology Obstetrics \& Reproductive Medicine, 25(2), 1. https://doi.org/10.21613/gorm.2018.778

Yimer, H., \& Woldie, H. (2019). Incidence and Associated Factors of Chronic Pain After Caesarean Section: A Systematic Review. Journal of Obstetrics and Gynaecology Canada, 41(6), 840-854. https://doi.org/10.1016/j.jogc.2018.04.006

Zafarghandi, N., Hadavand, S., Davati, A., Mohseni, S. M., Kimiaiimoghadam, F., \& Torkestani, F. (2012). The effects of sleep quality and duration in late pregnancy on labor and fetal outcome. Journal of Maternal-Fetal and Neonatal Medicine, 25(5), 535-537. https://doi.org/10.3109/14767058.2011.600370 